\title{
Strontium-based nanosized phosphates as anticorrosive fillers of epoxy and polyurethane coating compositions
}

\author{
Krzysztof Kowalczyk $^{1 *}$, Justyna Gołąbek ${ }^{1}$, Katarzyna Przywecka ${ }^{1}$, Barbara Grzmil ${ }^{2}$ \\ ${ }^{1}$ West Pomeranian University of Technology, Szczecin, Faculty of Chemical Technology and Engineering, Polymer Institute, \\ Piastów Ave. 42, 71-065 Szczecin, Poland \\ ${ }^{2}$ West Pomeranian University of Technology, Szczecin, Faculty of Chemical Technology and Engineering, Institute of \\ Inorganic Chemical Technology and Environmental Engineering, Piastów Ave. 42, 71-065 Szczecin, Poland \\ "Corresponding author: e-mail: kkowalczyk@zut.edu.pl
}

\begin{abstract}
Anticorrosive epoxy and polyurethane coatings were compounded using zinc-free nanosized phosphates of strontium (SP) or strontium and aluminum (SAP). For comparison, a nanosized calcium aluminum ammonium phosphate (CAP) and a microsized zinc phosphate (ZP) were tested. Results of salts spray and cyclic corrosion tests revealed better anticorrosive properties of the SAP-based coatings in relation to the samples with the other $\mathrm{Zn}$-free fillers or ZP. Electrochemical noise tests of uncoated steel in aqueous suspensions of the phosphates exhibited similar corrosion inhibition efficiency of the Sr-based phosphates and ZP, and worse anticorrosive features of CAP. Electrochemical impedance spectroscopy did not show better protective properties of ZP-based coatings than the samples with the Zn-free fillers.
\end{abstract}

Keywords: Strontium phosphate, strontium aluminum phosphate, calcium aluminum ammonium phosphate, zinc phosphate, anticorrosive coatings.

\section{INTRODUCTION}

Microsized zinc phosphates and phosphates of $\mathrm{Zn}$ and $\mathrm{Al}^{1,2,3,4}, \mathrm{Sr}^{5}, \mathrm{Fe}^{1,4,6}$ or $\mathrm{Ca}^{7}$ belong to the most effective anticorrosive fillers used in waterborne, solventborne, solventless and powder paints for steel substrates. Zinc-based phosphates exhibit much lower toxicity for humans and other mammals than prohibited red lead and zinc chromate (VI), but a negative influence of these phosphoric acids salts on many simple aquatic organisms has been lately revealed ${ }^{8}$. Thus, various types of zinc-free phosphates have been developed, especially these based on ammonium and/or $\mathrm{Al}^{2}, 9,10,11,12,13,14, \mathrm{Mg}^{15}$, $\mathrm{Ca}^{3,14,16,17}, \mathrm{Cr}, \mathrm{Mn}^{14}, \mathrm{Sr}^{2,3,5,17,18,19}, \mathrm{Ba}^{13,18}, \mathrm{~Pb}^{6}$. The scientific papers show that phosphate fillers containing $\mathrm{Al}$ or $\mathrm{Sr}$ exhibit relatively the best anticorrosive features in organic coatings applied onto steel. However, effect of these phosphates (especially the Sr-type salts) on the aquatic environment has not been widely studied, they are commonly considered as non-toxic additives. It should be noted that laboratory-estimated protective efficacy of coating systems depends on a type and content of anticorrosive fillers, but it can be also affected by a type of polymeric binder/matrix and used investigation methods (e.g. electrochemical tests of the anticorrosive fillers or accelerated tests of the coatings). Moreover, sizes of anticorrosive fillers particles and their dissipation efficiency in coating compositions should be considered as important parameters influencing properties of dry/ cured paints, 10, 11, 12. In this work, a Zn-free nanosized strontium phosphate (SP) and a strontium aluminum phosphate (SAP) were tested as anticorrosive fillers in primer-less solvent-borne $2 \mathrm{~K}$ coating compositions compounded using an epoxy or a polyurethane (i.e. polyacrylate-urethane) binder. These systems were compared with reference coatings filled with a nanosized calcium aluminum ammonium phosphate (CAP) and a commercial microsized zinc phosphate (ZP). Value of the L parameter (i.e. pigment volume concentration/ critical pigment volume concentration) for the prepared coating compositions was kept at 0.55 according to the literature data ${ }^{20}$. Anticorrosive features of the compositions were tested in different aggressive conditions by means of a salt spray chamber (continuous exposition of the samples in a fog containing $\mathrm{NaCl}$ ) and a cyclic chamber (exposition in a corrosive ammonium sulfate/ $\mathrm{NaCl}$-based fog with a drying stage). Barrier features of the systems were tested using an electrochemical impedance spectroscopy technique. Additionally, the protective efficiency of the phosphate was evaluated by a relatively novel electrochemical noise test using two bare steel substrates immersed in aerated aqueous suspensions of the fillers.

\section{EXPERIMENTAL}

Preparation of the anticorrosive epoxy paints

The following components were used for solvent-borne 2K epoxy paints preparation:

- Bisphenol A-based solid epoxy resin (E2), epoxy equivalent weight (EEW) 400 g/eqiv. (Epidian 2; Z.Ch. Organika-Sarzyna, Poland);

- Bisphenol A-based solid epoxy resin (E4), epoxy equivalent weight (EEW) 233 g/eqiv. (Epidian 4; Z.Ch. Organika-Sarzyna);

- polyaminoamide curing agent (S10/50), viscosity ca. $350 \mathrm{mPas}$ at $25^{\circ} \mathrm{C}$, amine value $90 \mathrm{mg} \mathrm{KOH} / \mathrm{g}$ (Saduramid 10/50; Z.Ch. Organika-Sarzyna);

- strontium phosphate (SP; ZUT, Poland);

- strontium aluminum phosphates (SAP; ZUT);

- calcium aluminum ammonium phosphate (CAP; ZUT);

- zinc phosphate (ZP) (Novinox ACE20, SNCZ, Fran-

ce) as a reference Zn-based anticorrosive filler;

- quartz powder (SF500), specific gravity (o ) 2.65 $\mathrm{g} / \mathrm{cm}^{3}$, oil adsorption (OA) $26 \mathrm{~g} / 100 \mathrm{~g}$ (Sikron SF500; Quarzwerke, Germany);

- talc (FM03), $\varrho=2.75 \mathrm{~g} / \mathrm{cm}^{3}$, OA $=49 \mathrm{~g} / 100 \mathrm{~g}$

(Finntalc M03-SQ, Mondo Minerals, Finland); 
- titanium dioxide $\left(\mathrm{TiO}_{2}\right), \mathrm{\varrho}=4.1 \mathrm{~g} / \mathrm{cm}^{3}, \mathrm{OA}=$ 21 g/100 g (Tytanpol R001, G.A.Z.Ch. Police, Poland); - wollastonite (HR325), $\mathrm{\varrho}=2.9 \mathrm{~g} / \mathrm{cm}^{3}, \mathrm{OA}=40 \mathrm{~g} / 100 \mathrm{~g}$ (Vansil HR325; Vanderbilt Minerals, USA);

- xylene (100 wt. parts), 1-butanol (20 wt. parts) and diisobutyl ketone (10 wt. parts) mixture as a solvent (POCh, Poland);

- wetting/dispersing additive based on a block copolymer (Disperbyk 2155, BYK-Chemie, Germany);

- silicone defoamer (BYK-066N, BYK-Chemie).

The epoxy paints were prepared as follows: A mixture of the E4 and E2 epoxy resins $(80 / 20 \mathrm{~m} / \mathrm{m})$ was dissolved in the solvents and mixed (450 rpm, $5 \mathrm{~min}$ ) with the auxiliary additives using the laboratory dissolver with a heavy-duty dispersion impeller (VMA Getzmann $\mathrm{GmbH}$, Germany). Then, a phosphate filler, $\mathrm{TiO}_{2}$ and SF500 were added to the composition and homogenized at $2800 \mathrm{rpm}$ for $30 \mathrm{~min}$. Next, FM03 and HR325 were incorporated and dispersed for $40 \mathrm{~min}$. The prepared dispersion was mixed with the S10/50 curing agent and stored at RT for $2 \mathrm{~h}$ before application on steel substrates. The paints components, phosphate fillers content, pigment volume concentration (PVC) and critical pigment volume concentration (CPVC) values were specified in Table 1.

\section{Preparation of the anticorrosive polyurethane paints}

The following components were used for solvent-borne $2 \mathrm{~K}$ polyurethane paints preparation:

- WorléeCryl A2218 (WA2218), 50\% solution of hydroxyacrylic resin in a xylene/butyl acetate mixture, viscosity ca. $1250 \mathrm{mPa} \cdot \mathrm{s}$ at $20^{\circ} \mathrm{C}$, hydroxyl value $58 \mathrm{mg}$ $\mathrm{KOH} / \mathrm{g}$ (on solids) (Worlée-Chemie $\mathrm{GmbH}$, Germany);

- Tolonate HDB-LV, hexamethylene diisocyanate derivative, viscosity ca. $2000 \mathrm{mPa} \cdot \mathrm{s}$ at $25^{\circ} \mathrm{C}, \mathrm{NCO}$ content 23.5 wt.\% (Vencorex, France);

- strontium phosphate (SP), strontium aluminum phosphates (SAP), calcium aluminum ammonium phosphate (CAP) and zinc phosphate (ZP) (Novinox ACE20);

- mica/quartz mixture (AF40), $\mathrm{Q}=2.75 \mathrm{~g} / \mathrm{cm}^{3}, \mathrm{OA}=$ $35 \mathrm{~g} / 100 \mathrm{~g}$ (Aspolit F40, Aspanger Bergbau \& Mineralwerke $\mathrm{GmbH}$, Austria);

- talc (FM-03), titanium dioxide $\left(\mathrm{TiO}_{2}\right)$ and wollastonite (HR325),

- xylene (90 wt. parts) and butyl acetate (10 wt. parts) mixture as a solvent;
- wetting/dispersing additive based on unsaturated polycarboxylic acid polymer (BYK-P 104S, BYK-Chemie $\mathrm{GmbH}$, Germany);

- silicone defoamer (BYK-067A, BYK-Chemie GmbH).

The polyurethane paints were prepared as follows: The WA2218 resin was mixed (450 rpm, $5 \mathrm{~min}$ ) with the auxiliary additives using the laboratory dissolver. Then, a phosphate filler, $\mathrm{TiO}_{2}$ and $\mathrm{AF} 40$ were added to the composition and homogenized at $2800 \mathrm{rpm}$ for 20 min. Next, FM03 and HR325 were incorporated and dispersed for $30 \mathrm{~min}$. The prepared dispersion was mixed with the solvents mixture and HDB-LV curing agent and stored at RT for 50 min before application on steel substrates. The paints components, phosphate fillers content, pigment volume concentration (PVC) and critical pigment volume concentration (CPVC) values were specified in Table 1.

\section{Coatings preparation}

The paints were applied with a brush (according to the Polish Standard PN-C-81514:1979) and leveled with a spiral film applicator $(150 \mathrm{~mm})$ onto the steel panels (Q-Panels, Q-Lab Europe, England) with the dimensions of $76 \times 152 \mathrm{~mm}$ (for electrochemical impedance spectroscopy (EIS) tests) and $102 \times 152 \mathrm{~mm}$ (for tests in a salt spray chamber and cyclic chamber). Two-layer samples were prepared by applying two layers of coating compositions with $24 \mathrm{~h}$ painting interval. The coatings were cured at room temperature for 14 days before testing.

\section{Characterization of the phosphate fillers}

The specific gravity of the phosphates fillers was measured using Ultrapyc $1200 \mathrm{e}$ helium autopycnometer (Quantachrome Inst., USA). The oil absorption for the mentioned phosphates was measured according to the PN-EN ISO 787-5 standard. The particle size of the fillers was analyzed using the laser scanning microscope VK9700 (Keyence, USA). The pH of aqueous suspensions (10 wt.\%) of the phosphate fillers was measured by means of Elmetron CP-401 pH-meter. Chemical composition of the nanofillers was determined by colorimetric vanadium-molybdenum method $\left(\mathrm{P}_{2} \mathrm{O}_{5}\right.$ content; Spekol 11, Carl Zeiss, Germany), spectrometric ICP-AES method (strontium, aluminum and zinc content; Optima 5300 DV, PerkinElmer, USA).

Electrochemical noise experiments for the uncoated steel substrate (Q-Panels) were performed using EN120 software and the FAS2 femtostat working in ZRA mode

Table 1. Composition of the epoxy and polyurethane coatings

\begin{tabular}{|c|c|c|c|c|c|c|c|c|}
\hline \multirow{2}{*}{$\begin{array}{c}\text { Coating type } \\
\text { Coating acronym }\end{array}$} & \multicolumn{4}{|c|}{ Epoxy } & \multicolumn{4}{|c|}{ Polyurethane } \\
\hline & EP/SP & EP/SAP & EP/CAP & $\mathrm{EP} / \mathrm{ZP}$ & $\mathrm{PU} / \mathrm{SP}$ & PU/SAP & PU/CAP & $\mathrm{PU} / \mathrm{ZP}$ \\
\hline Phosphate acronym & SP & SAP & CAP & ZP & SP & SAP & CAP & ZP \\
\hline Phosphate & \multicolumn{4}{|c|}{30} & \multicolumn{4}{|c|}{30} \\
\hline volume & \multicolumn{4}{|c|}{20} & \multicolumn{4}{|c|}{15} \\
\hline content & \multicolumn{4}{|c|}{15} & \multicolumn{4}{|c|}{15} \\
\hline Wollastonite & \multicolumn{4}{|c|}{5} & \multicolumn{4}{|c|}{5} \\
\hline Phosphate content $^{\text {a }}$ (vol\%) & 7.9 & 6.6 & 7.5 & 8.4 & 7.6 & 6.4 & 7.3 & 8.1 \\
\hline PVC & 26.2 & 22.0 & 25.0 & 27.9 & 25.4 & 21.4 & 24.3 & 27.0 \\
\hline CPVC & 47.7 & 40.0 & 45.5 & 50.7 & 46.2 & 38.9 & 44.2 & 49.0 \\
\hline$\Lambda^{\mathrm{b}}$ & \multicolumn{8}{|c|}{0.55} \\
\hline
\end{tabular}


(i.e. as a zero resistance ammeter) (Gamry, USA). Two steel samples were installed on the both sides of a horizontal glass cell filled with 0.1 wt. $\%$ suspension of a phosphate filler in 3.5 wt. $\% \mathrm{NaCl}$ aqueous solution (prepared $24 \mathrm{~h}$ before the test). The cell was equipped with a saturated calomel reference electrode, continuously aerated using compressed oil-free air and placed in a Faraday cage. The whole test consisted of thirteen measurements (with $2 \mathrm{~h}$ intervals) of current flow fluctuations between the identical steel samples (sample area of $3.14 \mathrm{~cm}^{2}$ ); each measurement was carried out for 1024 $\mathrm{s}$ (sampling intervals of $1 \mathrm{~s}$ ). The current noise density as a value of the root mean square (RMS) of amplitude of current flow density (registered for all measurements) as well as a total charge value (in relation to the density of current flow noise) were automatically calculated by the Echem Analyst software (Gamry). The corrosion inhibition efficiency $\left(\eta_{E N}\right)$ of the phosphate fillers was calculated according to the following equation:

$\eta_{E N}=\left[\frac{q_{0}-q}{q_{0}}\right] \times 100[\%]$

where $q_{0}$ and $q$ are charge density values for the steel substrates tested in 3.5 wt. $\% \mathrm{NaCl}$ aqueous solution and $0.1 \mathrm{wt} . \%$ suspension of a phosphate filler in the $3.5 \mathrm{wt} . \%$ $\mathrm{NaCl}$ aqueous solution, respectively.

\section{Characterization of the cured coatings}

The thickness of cured films was measured with the electronic film gauge Byko-test 8500 (BYK-Gardner, Germany) according to PN-EN ISO 2808. EIS tests were carried out with coated panels (two-layer epoxy coatings with a thickness of 155-171 $\mu \mathrm{m}$ and two-layer polyurethane coatings with a thickness of 138-167 $\mu \mathrm{m}$, three samples of each composition) after 0, 100 and 250 $\mathrm{h}$ of their immersion in the periodically air-saturated $\mathrm{NaCl}$ aqueous solution (3.5 wt.\%). A three-electrode vertical glass cell (with $14.5 \mathrm{~cm}^{2}$ surface sample area) equipped with a graphite counter electrode and a saturated calomel reference electrode was used inside the Faraday cage. The impedance data $(0.01-10000 \mathrm{~Hz}$, $30 \mathrm{mV}$ amplitude of sinusoidal voltage vs. OCP) were collected using EIS300 software with the FAS2 femtostat and analyzed using the electric circuit model presented in Fig. $1\left(\mathrm{R}_{\mathrm{u}}-\right.$ uncompensated solution resistance, $R_{p}$ - pore resistance, $C_{c}$ - coating capacitance). The pore resistance and coating capacitance parameters were calculated in respect to the coating thickness and presented as relative $R_{p}$ (i.e. $\left.R_{p r}, \mathrm{~W} / \mathrm{mm}\right)$ and relative $C_{c}\left(C_{c r}, \mathrm{~F} /\right.$ $\mathrm{mm}$ ) with standard deviations.

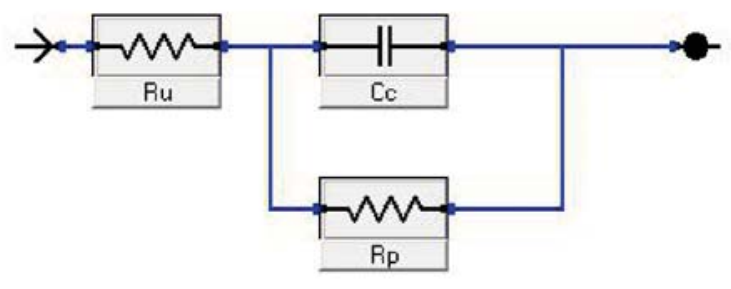

Figure 1. The electric circuit model for coatings before and after immersion in an aqueous $\mathrm{NaCl}$ solution
The salt spray test was carried out acc. to PN-EN ISO 9227 in CorrosionBox 400 (Co.fo.me.gra., Italy) using a $\mathrm{NaCl}$ aqueous solution (concentration of $50 \mathrm{~g} / \mathrm{l}$ ) sprayed with compressed oil-free air. Back side and edges of the steel panels with $\mathrm{x}$-cut coatings (acc. to EN ISO 17872) were protected and the samples were mounted at the angle of $20^{\circ}$ vertically. The temperature in the spray cabinet was maintained at $35^{\circ} \mathrm{C}$. The cyclic test was realized according to ASTM G85 Annex 5 using an aqueous solution of $\mathrm{NaCl}(5 \mathrm{~g} / \mathrm{l})$ and $\left[\mathrm{NH}_{4}\right]_{2} \mathrm{SO}_{4}(35 \mathrm{~g} / \mathrm{l})$ sprayed with compressed oil-free air. The test comprised 2-hour repetitive cycles: 1 -h exposure of the samples in the solution fog (at RT) and $1-\mathrm{h}$ drying at $35^{\circ} \mathrm{C}$.

\section{RESULTS AND DISSCUSION}

Electrochemical noise (EN) test results for the mild carbon steel immersed in the air-saturated aqueous $\mathrm{NaCl}$ solutions containing the phosphate fillers (or in the solution without a filler) are presented in Table 2. As can be seen, the lowest current noise density and charge density values were recorded for strontium phosphate (SP; $185 \mathrm{nA} / \mathrm{cm}^{2}$ and $14.4 \mathrm{mC} / \mathrm{cm}^{2}$ ) and strontium aluminum phosphate (SAP; $189 \mathrm{nA} / \mathrm{cm}^{2}$ and $14.4 \mathrm{mC} / \mathrm{cm}^{2}$, respectively). Slightly higher vales were noted for zinc phosphate (ZP; $212 \mathrm{nA} / \mathrm{cm}^{2}, 14.8 \mathrm{mC} / \mathrm{cm}^{2}$ ), however, the steel corrosion inhibition efficiency for these phosphates dispersions was similar (ca. $87 \%$ for SP, SAP and ZP). In the case of calcium aluminum ammonium phosphate (CAP) the corrosion protection efficiency was lower and reached ca. $80 \%$. Considering EN data for the nanosized phosphates, it can be supposed that the high corrosion inhibition features of SP and SAP (vs. CAP) resulted from strontium presence in the phosphates and/or relatively low $\mathrm{P}_{2} \mathrm{O}_{5}$ content (34.0 wt.\% in SP and 30.1 wt.\% in SAP); CAP does not contain $\mathrm{Sr}$, but only $\mathrm{Al}, \mathrm{Ca}$ and $\mathrm{NH}_{3}$ (39.8 wt. $\%$ of $\mathrm{P}_{2} \mathrm{O}_{5}$; Tab. 3). Comparison of the current noise densities for SP $\left(185 \mathrm{nA} / \mathrm{cm}^{2}, 44.8 \mathrm{wt} . \%\right.$ of $\mathrm{Sr}$ ) and SAP (189 nA/ $\mathrm{cm}^{2}, 35.1$ wt.\% of $\mathrm{Sr}$ ) shows that the former parameter (i.e. the $\mathrm{Sr}$ content) is more important than $\mathrm{P}_{2} \mathrm{O}_{5}$ concentration in the phosphate fillers. Arguably, other features of the tested pigments (particles size, water solubility) did not influence their protective properties during the EN test. Probably, the $\mathrm{NH}_{3}$ content and a relatively high Ca concentration in CAP caused a markedly higher $\mathrm{pH}$ value of this filler suspension $(\mathrm{pH}=9.5$, Table 3$)$ in relation to the other phosphates (6.7-7.8). Nevertheless, taking into account results presented in the literature? ${ }^{9}$, that parameter should not negatively affect anticorrosive efficiency of the CAP aqueous dispersion. Observation of the current noise density spectra (vs. immersion time of the steel

Table 2. Electrochemical noise tests results for steel immersed in phosphate fillers suspensions in 3.5 wt. $\% \mathrm{NaCl}$ aqueous solution

\begin{tabular}{|l|c|c|c|}
\hline $\begin{array}{l}\text { Phosphate } \\
\text { type }\end{array}$ & $\begin{array}{c}\text { Current noise } \\
\text { density } \\
{\left[\mathrm{nA} / \mathrm{cm}^{2}\right]}\end{array}$ & $\begin{array}{c}\text { Charge density } \\
{\left[\mathrm{mC} / \mathrm{cm}^{2}\right]}\end{array}$ & $\begin{array}{c}\text { Corrosion } \\
\text { inhibition } \\
\text { efficiency [\%] }\end{array}$ \\
\hline $\begin{array}{l}\text { No } \\
\text { phosphate }\end{array}$ & 1263 & 111.4 & - \\
\hline SP & 185 & 14.4 & 87.1 \\
\hline SAP & 189 & 14.4 & 87.1 \\
\hline CAP & 265 & 22.0 & 80.3 \\
\hline ZP & 212 & 14.8 & 86.7 \\
\hline
\end{tabular}


Table 3. Physical and chemical properties of the phosphate fillers

\begin{tabular}{|c|c|c|c|c|}
\hline Phosphate acronym & $\mathrm{SP}^{\mathrm{a}, \mathrm{b}}$ & SAP & $\mathrm{CAP}^{\mathrm{a}, \mathrm{b}}$ & ZP \\
\hline Density $\left[\mathrm{g} / \mathrm{cm}^{3}\right]$ & 3.2 & $2.9^{a}$ & 2.1 & 3.2 \\
\hline Oil adsorption $[\mathrm{g} / 100 \mathrm{~g}]$ & 37 & $84^{a}$ & 70 & 25 \\
\hline $\begin{array}{l}\text { Average particles diameter } \\
\text { [nm] }\end{array}$ & 356 & 334 & 310 & $\leq 32000^{c}$ \\
\hline Water solubility [wt\%] & 0.28 & 0.65 & 0.87 & 0.28 \\
\hline $\mathrm{pH}^{\mathrm{d}}$ & 6.7 & 7.8 & 9.5 & 7.0 \\
\hline $\mathrm{P}_{2} \mathrm{O}_{5}$ content [wt $\left.\%\right]$ & 34.0 & 30.1 & 39.8 & 30.9 \\
\hline Sr content [wt\%] & 44.8 & 35.1 & 0 & 0 \\
\hline Al content [wt\%] & 0 & 4.5 & 7.2 & 0 \\
\hline Ca content [wt\%] & 0 & 0 & 13.7 & 0 \\
\hline $\mathrm{NH}_{3}$ content [wt $\%$ ] & 0 & 0 & 3.2 & 0 \\
\hline Zn content [wt $\%]$ & 0 & 0 & 0 & 44.7 \\
\hline
\end{tabular}

$\mathrm{a}-{ }^{9} ; \mathrm{b}-{ }^{21} ; \mathrm{c}-$ the producer data; $\mathrm{d}-\mathrm{pH}$ values for phosphate aqueous extracts

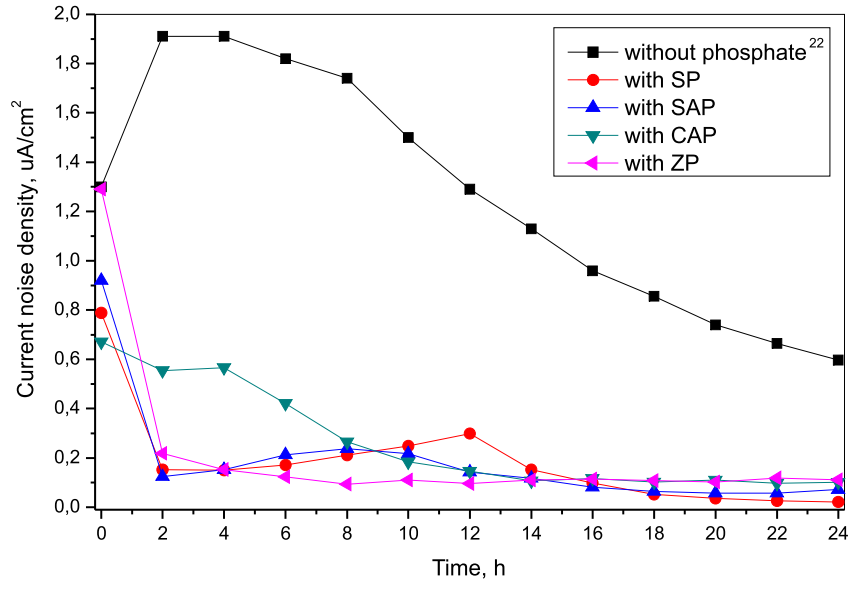

Figure 2. Current noise density variation during electrochemical noise test of steel substrates in the phosphate dispersions in 3.5 wt. $\% \mathrm{NaCl}$ aqueous solution

samples; Fig. 2) shows that CAP exhibited high initial anticorrosive features (i.e. a low current noise density at the beginning of the EN test) in relation to SP, SAP and ZP samples, but it was constant for ca. $4 \mathrm{~h}$ of the test. Finally, it resulted in the low corrosion inhibition efficacy value $(80 \%)$ in comparison to the other systems (however, amounts of steel corrosion products were similar for CAP, SAP and ZP; Figs. 3C, 3D and 3E).

Generally, the EN results for the zinc-free phosphates correlate with outcomes of accelerated corrosion tests of coated steel samples realized in the salt spray chamber
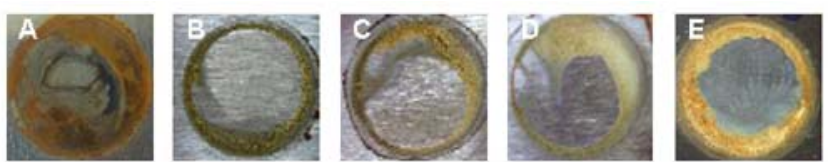

Figure 3. The macrographs of steel substrates after electrochemical noise test in $3.5 \mathrm{wt} \% \mathrm{NaCl}$ aqueous solution containing: no phosphate filler (A) or with SP (B), SAP (C), CAP (D) and ZP (E)

(Table 4) and in the cyclic chamber (Table 5). Considering the epoxy coatings, the lowest values of averaged (ADS) and maximal (MDS) delamination around the scribe were registered for layers with the fillers exhibiting the highest corrosion inhibition efficacy (Table 2), i.e. SP (EP/SP) and SAP filler (EP/SAP). In the case of salt spray chamber test, these parameters reached 1.5-4.0 $\mathrm{mm}$ and 2-7 $\mathrm{mm}$ for EP/SP (ADS and MDS in the range of $250-1000 \mathrm{~h}$ of the tests), or $1.4-4.1 \mathrm{~mm}$ and 2-6 mm for EP/SAP. For the other epoxy systems, adhesive failures around the scribe of the EP/CAP (ADS: 2.7-5.0 mm, MDS: 3-7 mm) and EP/ZP (ADS: 2.3-4.8 mm, MDS: $4-8 \mathrm{~mm}$ ) were similar, however, the former system exhibited higher blistering resistance. After $250 \mathrm{~h}$ of their exposition in the salt fog, blisters were observed only for the epoxy coatings filled with the zinc phosphate (2(S2), Table 4) Perhaps it was caused by significantly higher relative pore resistance $\left(\mathrm{R}_{\mathrm{pr}}\right)$ observed at the beginning of electrochemical impedance spectroscopy (EIS) tests of the EP/CAP samples $(28.7 \mathrm{M} \Omega / \mu \mathrm{m}$; Fig.

Table 4. Delamination values and blistering degrees of coated steel panels exposed in the salt spray chamber

\begin{tabular}{|c|c|c|c|c|c|c|c|c|}
\hline \multirow{2}{*}{$\begin{array}{c}\text { Salt spray } \\
\text { test duration [h] }\end{array}$} & \multicolumn{4}{|c|}{ Epoxy coatings } & \multicolumn{4}{|c|}{ Polyurethane coatings } \\
\hline & EP/SP & EP/SAP & EP/CAP & $\mathrm{EP} / \mathrm{ZP}$ & PU/SP & PU/SAP & PU/CAP & PU/ZP \\
\hline \multicolumn{9}{|c|}{ Delamination around the scribe ${ }^{\mathrm{a}}[\mathrm{mm}]$} \\
\hline 250 & $1.5 \pm 0.6^{b}(2)^{c}$ & $1.4 \pm 0.5(2)$ & $2.7 \pm 0.7(3)$ & $2.3 \pm 1.3(4)$ & $3.0 \pm 1.0(4)$ & $3.0 \pm 0.0(3)$ & $2.4 \pm 0.9(4)$ & $0(0)$ \\
\hline 500 & $2.5 \pm 0.5(3)$ & $2.6 \pm 0.8(3)$ & $3.2 \pm 0.9(3)$ & $3.9 \pm 1.5(6)$ & $3.9 \pm 0.9(5)$ & $4.1 \pm 1.7(7)$ & $4.3 \pm 1.9(9)$ & $3.8 \pm 2.2(7)$ \\
\hline 1000 & $4.0 \pm 0.8(7)$ & $4.1 \pm 0.9(6)$ & $5.0 \pm 1.1(7)$ & $4.8 \pm 1.1(8)$ & $6.7 \pm 3.2(15)$ & $6.7 \pm 2.0(11)$ & $6.3 \pm 2.7(13)$ & $7.9 \pm 2.1(11)$ \\
\hline & \multicolumn{8}{|c|}{ Blistering outside the scribe $^{d}$} \\
\hline 250 & - & - & - & $2(\mathrm{~S} 2)$ & - & - & - & - \\
\hline 500 & - & - & 2(S2) & 2(S2) & - & - & - & - \\
\hline 1000 & - & - & 2(S2) & 2(S2) & $5(\mathrm{~S} 1)$ & - & - & $5(\mathrm{~S} 1)$ \\
\hline
\end{tabular}




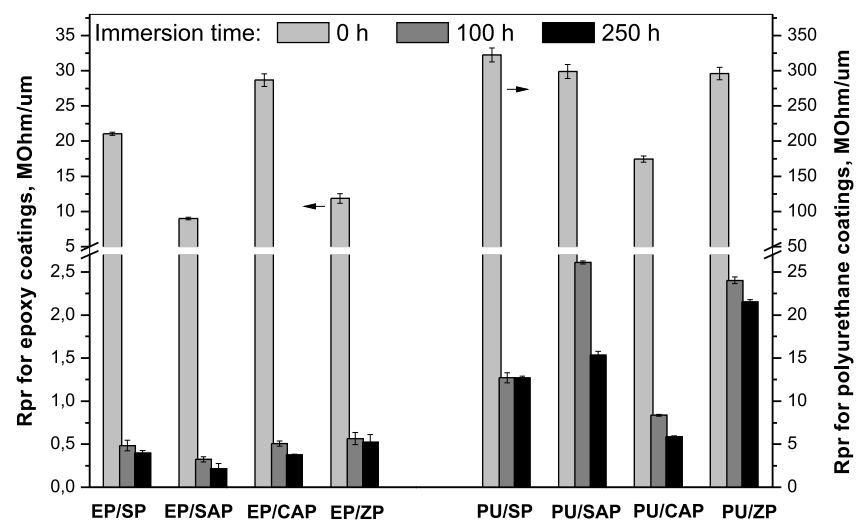

Figure 4. Relative pore resistance $\left(\mathrm{R}_{\mathrm{pr}}\right)$ variation of coatings during immersion in an aqueous $\mathrm{NaCl}$ solution

4) in comparison with EP/ZP (11.9 M $\Omega / \mu m)$. Nevertheless, further tests revealed similar values of $R_{p r}$ (EIS) and blistering (salt spray technique, 2(S2); Table 4) for the EP/CAP and EP/ZP samples. It should be noted that these systems were characterized by much higher values of initial relative coating capacitance $\left(\mathrm{C}_{\mathrm{cr}} ; 0 \mathrm{~h}\right.$, Fig. 5) than EP/SP and EP/SAP (thus, the coatings with the Sr-based nanofillers reached lower ADS and MDS than EP/CAP and EP/ZP during accelerated corrosion tests; Table 4 and Table 5). It means that porosity of $\mathrm{EP} / \mathrm{SP}$ and $\mathrm{EP} / \mathrm{SAP}$ (before their immersion in the $\mathrm{NaCl}$ aqueous solution) was limited. On the other hand, $\mathrm{C}_{\mathrm{cr}}$ values for EP/CAP ( $7.8 \mathrm{pF} / \mu \mathrm{m}$ after $100 \mathrm{~h}$ and $8.8 \mathrm{pF} / \mu \mathrm{m}$ after $250 \mathrm{~h}$ of the immersion) were significantly higher in comparison to the other epoxy systems $(6.2$ and $6.9 \mathrm{pF} /$ $\mu \mathrm{m}$ for EP/SP, 5.1 and $5.9 \mathrm{pF} / \mu \mathrm{m}$ for EP/SAP, 6.1 and 6.2 $\mathrm{pF} / \mathrm{um}$ for $\mathrm{EP} / \mathrm{ZP})$. According to our previous report ${ }^{9}$,

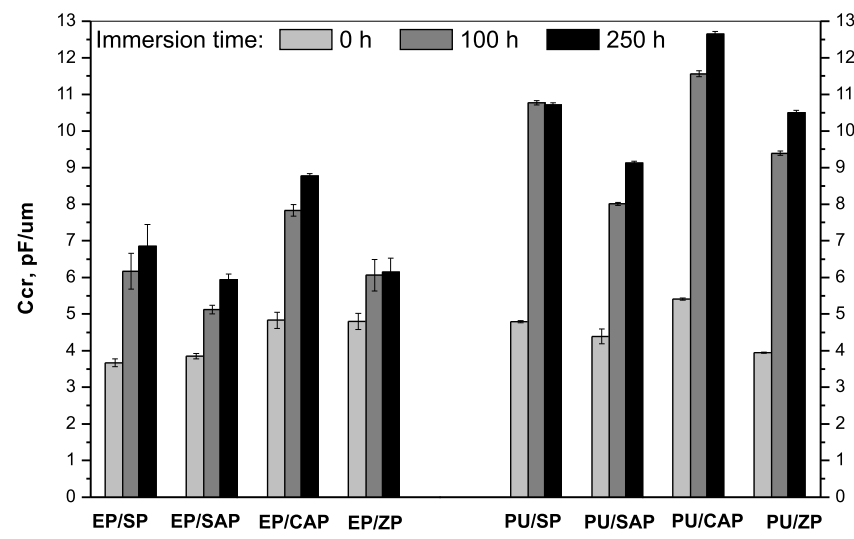

Figure 5. Relative coating capacitance $\left(\mathrm{C}_{\mathrm{cr}}\right)$ variation of coatings during immersion in an aqueous $\mathrm{NaCl}$ solution it could be explained by the higher water solubility of CAP $(0.87$ wt. \%) than the other phosphates $(0.28-0.65$ wt.\%; Table 3).

In the case of the cyclic corrosion tests (Tab. 5), ADS and MDS for EP/SP and EP/SAP reached 1.1-2.2 mm and $2-3 \mathrm{~mm}$ (the SP-based system) or $1.5-2.0 \mathrm{~mm}$ and 2-4 $\mathrm{mm}$ (the SAP-based system). Considering the other epoxy coatings, lower values of that parameters were registered for EP/CAP (1.4-2.3 mm and 3-4 mm, respectively) than for EP/ZP (2.4-4.0 $\mathrm{mm}$ and 5-8 $\mathrm{mm})$. It is noteworthy that blistering of these coatings has not been observed. Generally, it can be claimed that results of the accelerated corrosion tests revealed better anticorrosive features of the epoxy coatings filled with SP or SAP (the higher $\eta_{E N}$ ) in comparison to calcium aluminum ammonium phosphate or zinc phosphate-based samples (the lower $\eta_{E N}$, Tab. 2). Moreover, images of coated steel plates (after their exposition in the salt spray chambers; Fig. 6) show relatively smaller amounts
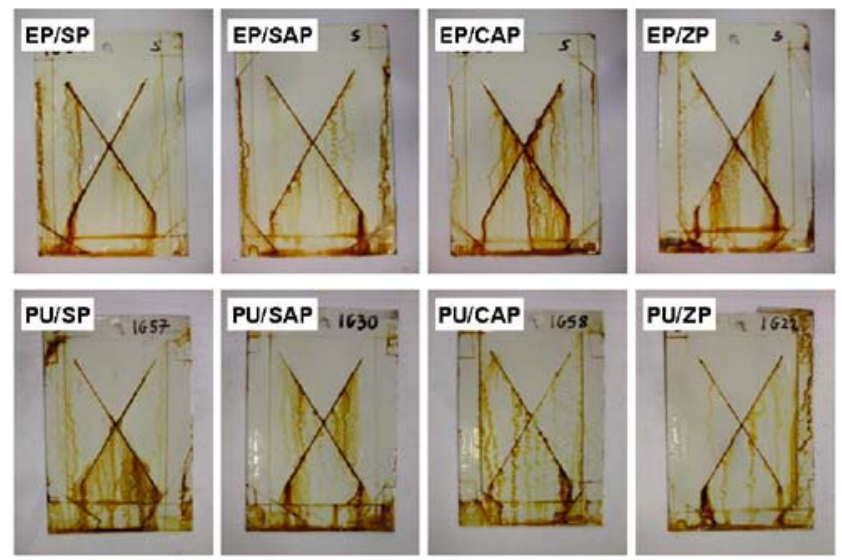

Figure 6. The macrographs of coated steel samples after tests in the salt spray chamber

of steel corrosion products on the surfaces of EP/SP and EP/SAP coatings.

Considering steel samples covered with the polyurethane coatings, it can be claimed that the sample with ZP was slightly less corroded after the salt spray test in relation to the other PU-type systems (Fig. 6). The PU/ZP system did not exhibit delamination around the scribe after $250 \mathrm{~h}$ of the test, however, after long-lasting examination in the cabinet (500-1000 h), its ADS $(3.8-7.9 \mathrm{~mm})$ and MDS values $(7-11 \mathrm{~mm})$ were similar

Table 5. Delamination values and blistering degrees of coated steel panels exposed in the cyclic chamber

\begin{tabular}{|c|c|c|c|c|c|c|c|c|}
\hline \multirow{2}{*}{$\begin{array}{c}\text { Cyclic } \\
\text { test duration [h] }\end{array}$} & \multicolumn{4}{|c|}{ Epoxy coatings } & \multicolumn{4}{|c|}{ Polyurethane coatings } \\
\hline & EP/SP & EP/SAP & EP/CAP & $\mathrm{EP} / \mathrm{ZP}$ & $\mathrm{PU} / \mathrm{SP}$ & PU/SAP & $\mathrm{PU} / \mathrm{CAP}$ & $\mathrm{PU} / \mathrm{ZP}$ \\
\hline \multicolumn{9}{|c|}{ Delamination around the scribe ${ }^{a}(\mathrm{~mm})$} \\
\hline 250 & $1.1 \pm 0.4^{b}(2)^{c}$ & $1.50 .5(2)$ & $1.4 \pm 0.6(3)$ & $2.4 \pm 1.0(5)$ & $1.4 \pm 0.5(2)$ & $1.7 \pm 0.7(3)$ & $2.2 \pm 0.9(5)$ & $1.5 \pm 0.5(2)$ \\
\hline 500 & $1.4 \pm 0.5(2)$ & $1.70 .5(2)$ & $1.8 \pm 0.8(3)$ & $3.2 \pm 1.8(7)$ & $1.9 \pm 0.6(3)$ & $2.3 \pm 0.6(3)$ & $3.31 .6(8)$ & $2.2 \pm 1.0(5)$ \\
\hline \multirow[t]{2}{*}{1000} & $2.2 \pm 0.8(3)$ & $2.0 \pm 0.9(4)$ & $2.3 \pm 0.7(4)$ & $4.0 \pm 1.6(8)$ & $3.5 \pm 1.3(8)$ & $2.9 \pm 0.6(4)$ & $5.1 \pm 1.6(10)$ & $4.4 \pm 1.5(8)$ \\
\hline & \multicolumn{8}{|c|}{ Blistering outside the scribe $^{d}$} \\
\hline 1000 & - & - & - & - & - & - & - & - \\
\hline
\end{tabular}


and/or higher in comparison to the coatings filled with the zinc-free phosphates (ADS: 3.9-6.7 mm, MDS: 5-15; Table 4). Nevertheless, PU/ZP as well as PU/ SP were slightly blistered at the end of the test in the salt spray fog, thus it seems that the coatings with SAP filler reached the best protective features (ADS: 3.0-6.7 mm, MDS: 3-11 mm, no blisters). That coating system was characterized by relatively high $\mathrm{R}_{\mathrm{pr}}(299-15.3 \mathrm{M} \Omega /$ $\mu \mathrm{m}, 0-250 \mathrm{~h}$ of immersion, Fig. 4) and low $\mathrm{C}_{\mathrm{cr}}$ values (4.4-9.1 pF/um, Fig. 5) than the other samples (322-12.7 $\mathrm{M} \Omega / \mu \mathrm{m}$ and $4.8-10.7 \mathrm{pF} / \mu \mathrm{m}$ for PU/SP, $175-5.9 \mathrm{M} \Omega / \mu \mathrm{m}$ and 5.4-12.7 pF/ $\mu \mathrm{m}$ for PU/CAP, 296-22.5 $\mathrm{M} \Omega / \mu \mathrm{m}$ and 3.9-10.5 $\mathrm{pF} / \mu \mathrm{m}$ for PU/ZP).

Generally, similar situation was observed for the polyurethane coatings exposed in the cyclic chamber. At the beginning of the test, the best protective features were noted for PU/SP and PU/ZP (ADS: ca. $1.5 \mathrm{~mm}$, MDS: $2 \mathrm{~mm}$; Table 5), but after $500 \mathrm{~h}$ the lowest MDS values were noted for PU/SP and PU/SAP $(3 \mathrm{~mm})$. Finally $(1000 \mathrm{~h})$, PU/SAP exhibited the lowest values of both parameters: i.e. $2.9 \mathrm{~mm}$ (ADS) and $4 \mathrm{~mm}$ (MDS). The other PU-type samples reached 3.5-5.1 mm (ADS) and 8-10 mm (MDS). In detail, these results confirmed the worse corrosion inhibition efficiency of CAP calculated on a basis of the EN results (80.1\% Table 2). Moreover, it is noteworthy that PU/CAP was characterized by the lowest $\mathrm{R}_{\mathrm{pr}}$ and the highest $\mathrm{C}_{\mathrm{cr}}$ values in comparison to the other tested polyurethane coatings (Fig. 4, Fig. 5). As mentioned above (see: $C_{c r}$ for EP/CAP), the latter observation could be explained by the higher water solubility of the CAP filler (than SP, SAP and ZP; Table 3). Arguably, it resulted in reduction of $\mathrm{R}_{\mathrm{pr}}$ parameter of PU/CAP as well. As can be observed, all the polyurethane systems reached markedly higher $\mathrm{R}_{\mathrm{pr}}$ values than epoxy-based materials (Fig. 4). Probably, higher conductivity of the latter layers was affected by a presence of a hydrophilic unreacted amine component (the hardener) in the polymer matrix. An aqueous solution of amine can act as a good electrolyte, thus $\mathrm{R}_{\mathrm{pr}}$ of the EP-type coatings was limited. In this case, features of incorporated phosphate did not detectably affect the EIS test results for cured epoxy compositions.

Nevertheless, in the case of comparison of corrosion protection efficiency of epoxy and polyurethane coatings with the investigated phosphates, their concentration in the cured layers should be analysed. The systems were compounded at the constant PVC/CPVC ratio $(\Delta=0.55$, Tab. 1), thus phosphates volumetric content in the tested coatings varied from 6.6 to 8.4 vol.\% (EP) and from 6.4 to 8.1 vol.\% (PU). However, the concentration of the nanosized phosphates in the coatings was generally lower in comparison to the microsized $\mathrm{Zn}$-based phosphate, the lowest values of that parameter (the both coating systems) were reached for the SAP filler. Thus, it should be pointed out that strontium aluminum phosphate offers the best anticorrosive features of the low-filled epoxy and polyurethane coatings (during their exposition in the salt spray and cyclic chambers) in comparison to systems containing higher volumetric amounts of strontium phosphate, calcium aluminum ammonium phosphate or zinc phosphate. Moreover, weight content of the SAP filler in the investigated samples was much lower (ca. 12.4 and 13.7 wt.\%) than ZP (15.8 and 16.2 wt.\%) as well.

\section{CONCLUSIONS}

Anticorrosive 2K solvent-borne epoxy and polyurethane coatings filled with nanosized strontium-based phosphates (i.e. strontium phosphate SP, and strontium aluminum phosphate SAP) were prepared on steel substrates and tested. For comparison, coating systems based on a nanosized calcium aluminum ammonium phosphate (CAP) and a microsized zinc phosphate (ZP) were investigated. Considering accelerated and electrochemical tests results for the coating systems (compounded at $\mathrm{PVC} / \mathrm{CPVC}=$ 0.55 ) and for the raw phosphate fillers, the following conclusions can be drawn:

- The epoxy coatings with the strontium-based phosphates exhibited reduced values of averaged (ADS) and maximal delamination around the scribe (MDS) during their exposition for $1000 \mathrm{~h}$ in a salt spray chamber $(4.0$ $\mathrm{mm}$ and $7 \mathrm{~mm}$ for EP/SP, $4.1 \mathrm{~mm}$ and $6 \mathrm{~mm}$ for EP/ $\mathrm{SAP})$ or in a cyclic chamber $(2.2 \mathrm{~mm}$ and $3 \mathrm{~mm}$ for $\mathrm{EP} /$ $\mathrm{SP}, 2.0 \mathrm{~mm}$ and $4 \mathrm{~mm}$ for $\mathrm{EP} / \mathrm{SAP}$ ) in relation to the coatings with CAP and ZP; additionally, the EP/CAP and $\mathrm{EP} / \mathrm{ZP}$ samples have blistered during the accelerated corrosion tests.

- The polyurethane coatings with the SAP filler reached relatively lower ADS and MDS values during their exposition for $1000 \mathrm{~h}$ in the salt spray chamber $(6.7 \mathrm{~mm}$ and $11 \mathrm{~mm})$ or in the cyclic chamber $(2.9 \mathrm{~mm}$ and 4 $\mathrm{mm}$ ) in comparison to other coating systems.

- The salt spray test results for the coatings mostly corroborated electrochemical noise data recorded for uncoated steel substrates immersed in the fillers dispersions in an aqueous $\mathrm{NaCl}$ solution (e.g. the CAP filler exhibited lower corrosion inhibition efficiency than the other nanosized phosphates).

- The results of the electrochemical impedance spectroscopy measurements of the phosphate-filled coatings did not directly correlate with the salt spray and cyclic chambers test outcomes, however, these experiments revealed that ZP-filled epoxy and polyurethane coatings do not exhibit significantly better barrier/anticorrosive features than the samples with $\mathrm{Zn}$-free phosphates.

\section{ACKNOWLEDGEMENTS}

Work financed by the National Centre for Research and Development (NCBiR, Poland) under the "Tango" project (TANGO1/266477/NCBR/2015; 2015-2018). Some of the results were presented at "Antykorozja" scientific conference (21-23.03.2018, Ustroń-Jaszowiec, Poland).

\section{LITERATURE CITED}

1. Roselli, S., Romagnoli, R. \& Deyá, C. (2017). The anti-corrosion performance of water-borne paints in long term tests. Prog. Org. Coat. 109, 172-178. DOI: 10.1016/j.porgcoat.2017.04.031.

2. Heydarpour, M., Zarrabi, A., Attar, M. \& Ramezanzadeh, B. (2014). Studying the corrosion protection properties of an epoxy coating containing different mixtures of strontium aluminum polyphosphate (SAPP) and zinc aluminum phosphate (ZPA) pigments. Prog. Org. Coat. 77, 160-167. DOI: 10.1016/j. porgcoat.2013.09.003.

3. Kalendová, A. (2003). Comparison of the anticorrosion efficiencies of pigments based on condensed phosphates and polyphosphosilicates. Anti-corr. Meth. Mater. 50, 82-90. 10.1108/00035590310463957. 
4. del Amo, B., Romagnoli, R., Deyá, C. \& González, J. (2002). High performance water-based paints with non-toxic anticorrosive pigments. Prog. Org. Coat. 45, 389-397. DOI: 10.1016/S0300-9440(02)00125-X.

5. Ahmed, N., Mohamed, M., Mabrouk, M. \& ElShami, A. (2015). Novel anticorrosive pigments based on waste material for corrosion protection of reinforced concrete steel. Constr. Build. Mater. 98, 388-396. DOI: 10.1016/j.conbuildmat.2015.08.111.

6. Bethencourt, M., Botana, F., Marcos, M., Osuna, R. \& Sánchez-Amaya, J. (2003). Inhibitor properties of "Green" pigments for paints. Prog. Org. Coat. 46, 280-287. DOI: 10.1016/ S0300-9440(03)00013-4.

7. Naderi, R., Arman, S. \& Fouladvand, S. (2014). Investigation on the inhibition synergism of new generations of phosphate-based anticorrosion pigments. Dyes Pigm. 105, 23-33. DOI: 10.1016/j.dyepig.2014.01.015.

8. de Lima-Neto, P., de Araújo, A., Araújo, W. \& Correia, A. (2008). Study of the anticorrosive behaviour of epoxy binders containing non-toxic inorganic corrosion inhibitor pigments. Prog. Org. Coat. 62, 344-350. DOI: 10.1016/j.porgcoat.2008.01.012.

9. Kowalczyk, K. Przywecka, K. \& Grzmil, B. (2018). Influence of novel ammonium-modified zinc-free phosphate nanofillers on anticorrosive features of primer-less polyurethane top-coating compositions. J. Coat. Technol. Res. DOI: 10.1007/ s11998-018-0119-7.

10. Kowalczyk, K., Łuczka, K. \& Grzmil, B. (2015). Preparation and characterization of anticorrosion polyurethane paints and coats based on novel Zn-free phosphates." J. Coat. Technol. Res. 12, 153-165. DOI: 10.1007/s11998-018-0119-7.

11. Kowalczyk, K., Łuczka, K., Grzmil, B. \& Spychaj, T. (2013). Anticorrosive 2K polyurethane paints based on nanoand microphosphates with high dispersing additive content. Prog. Org. Coat. 76, 1088-1094. DOI: 10.1016/j.porgcoat.2013.03.003.

12. Kowalczyk, K., Łuczka, K., Grzmil, B. \& Spychaj, T. (2012). Anticorrosive polyurethane paints with nano- and microsized phosphates. Prog. Org. Coat. 74, 151-157. DOI: 10.1016/j.porgcoat.2011.12.003.

13. Kalendová, A., Veselý, D. \& Brodinová, J. (2004). Anticorrosive spinel-type pigments of the mixed metal oxides compared to metal polyphosphates. Anti-Corr. Meth. Mater. 51, 6-17. DOI: 10.1108/00035590410512681.

14. Jašková, V. \& Kalendová, A. (2012). Anticorrosive coatings containing modified phosphates. Prog. Org. Coat. 75, 328-334. DOI: 10.1016/j.porgcoat.2012.07.019.

15. Gorodylová, N., Dohnalová, Ž., Šulcová, P., Bělina, P. \& Vlček, M. (2016). Influence of synthesis conditions on physicochemical parameters and corrosion inhibiting activity of strontium pyrophosphates $\mathrm{SrM}^{\mathrm{II}} \mathrm{P}_{2} \mathrm{O}_{7}\left(\mathrm{M}^{\mathrm{II}}=\mathrm{Mg}\right.$ and $\left.\mathrm{Zn}\right)$. Prog. Org. Coat. 93, 77-86. DOI: 10.1016/j.porgcoat.2016.01.004.

16. Abd El-Ghaffar, M., Youssef, E. \& Ahmed, N. (2004). High performance anticorrosive paint formulations based on phosphate pigments. Pig. Res. Technol. 33, 226-237. DOI: 10.1108/03699420410546917.

17. Kalenda, P., Kalendová, A. \& Veselý, D. (2006). Properties of anticorrosion pigments depending on their chemical composition and PVC value. Pig. Res. Technol. 35/4, 188-199. DOI: $10.1108 / 03699420610677181$.

18. Kalendová, A. (2002). Comparison of the efficiencies of anticorrosive pigments based on chemically modified phosphates. Anti-Corr. Meth. Mater. 49, 364-372. DOI: 10.1108/00035590210440746.

19. Naderi, R., Mahdavian, M. \& Darvish, A. (2013). Electrochemical examining behavior of epoxy coating incorporating zinc-free phosphate-based anticorrosion pigment. Prog. Org. Coat., 76, 302-306. DOI: 10.1016/j.porgcoat.2012.09.026.

20. Gawri, S. \& Balakrishnan, K. (1994). The effect of the $\mathrm{PVC} / \mathrm{CPVC}$ ratio on the corrosion resistance properties of organic coatings. Prog. Org. Coat. 23, 363-377. DOI: 10.1016/00330655(94)87005-5.
21. Przywecka, K., Grzmil, B.\& Kowalczyk, K. (2018). Modyfikacja powierzchniowa i badanie właściwości fizykochemicznych antykorozyjnych pigmentów fosforanowych. In Z . Lendzion-Bieluń \& D. Moszyński (Eds.), Postępy w technologii i inżynierii chemicznej 2018 (pp. 192-200). Szczecin: WU ZUT w Szczecinie.

22. Przywecka, K., Grzmil, B. \& Kowalczyk, K. (2019). Anticorrosive and physicochemical properties of modified phosphate pigments. Polish J. Chem. Tech. 21, 20-23. DOI: 10.2478/pjct-2019-0004. 